\title{
Establishment of national reference for bunyavirus nucleic acid detection kits for diagnosis of SFTS virus
}

\author{
Xu Lu, Ling Wang, Dongting Bai and Yuhua Li
}

\begin{abstract}
Background: Severe fever with thrombocytopenia syndrome (SFTS) caused by SFTS virus (SFTSV) usually have a high fatality. At present no effective therapy or vaccine are available, so early diagnosis of SFTS is crucial to prevent and control SFTSV infection. This study aimed to establish a national reference for these diagnostic kits of SFTSV genome and make the diagnosis of the disease effective.

Methods: Six SFTSV strains isolated from different regions, and five relative viruses with similar clinical manifestations were selected as positive and negative references and assessed using real time quantitative PCR (q-PCR) using specific primers and probe and two commercial kits. The stability of the references was also assessed at $37^{\circ} \mathrm{C}$, room temperature or $-70^{\circ} \mathrm{C}$ for 8 days, 14 days or 8 months respectively, or following several cycles of freezing-thawing. Collaborative calibration of the references was performed by three labs.
\end{abstract}

Results: The references indicated good accuracy and specificity. The lowest detection limit was $10^{2} \mathrm{U} / \mathrm{mL}$. The accuracy was coefficient of variation less than $5 \%$. The references were highly stable at high temperatures and after long storing and freezing-thawing treatment.

Conclusions: We successfully established a national reference with good accuracy, high specificity, sensitivity and stability, which can be applied for quality control of commercial SFTSV diagnostic kits, thus preventing and controlling SFTS.

Trial registration: The references have been finished and it was retrospectively registered in the following article.

Keywords: SFTSV, Viral nucleic acid detection kit, Reference, q-PCR

\section{Background}

In 2007, some patients with severe fever, gastrointestinal bleeding and thrombocytopenia syndrome were first discovered in central and eastern China $[1,2]$, but the pathogen cannot be determined. The pathogen responsible for the syndrome was not identified until a novel Phlebovirus (family Bunyaviridae) named Sever Fever Thrombocytopenia Syndrome virus (SFTSV), was isolated from a sample collected from a patient in Henan Province in China at 2009 [3]. Then the cases were successively reported in Korea and Japan [4-6].

SFTSV, like other viruses in genus Phlebovirus, is an enveloped, segmented minus-strand RNA virus.

\footnotetext{
* Correspondence: lyhchengdu@163.com

Key Laboratory of the Ministry of Health for Research on Quality and Standardization of Biotech Products, National Institutes for Food and Drug Control, Beijing 100050, People's Republic of China
}

The genome consists of three segments: L (large), M (middle) and $\mathrm{S}$ (small), which respectively encode the RNA-dependent RNA polymerase, Gn-Gc envelope glycoproteins, nucleocapsid and non-structural proteins [3].

SFTSV infection is clinically characterized by fever, thrombocytopenia and leukopenia, gastrointestinal symptoms, and multiorgan dysfunction. The initial case fatality of SFTSV infection was 30\% [3, 7] in China and according to the national surveillance data, the case fatality from 2011 to 2014 was $7.9 \%$ [8].

Early clinical diagnosis of SFTSV infection is crucial for controlling the spread of SFTS. Generally, infection is confirmed via detection of viral genome or virus-specific antibodies in the patient's blood or serum [9]. Several SFTSV RNA detection kits are currently available [10-12]. However, no references are 


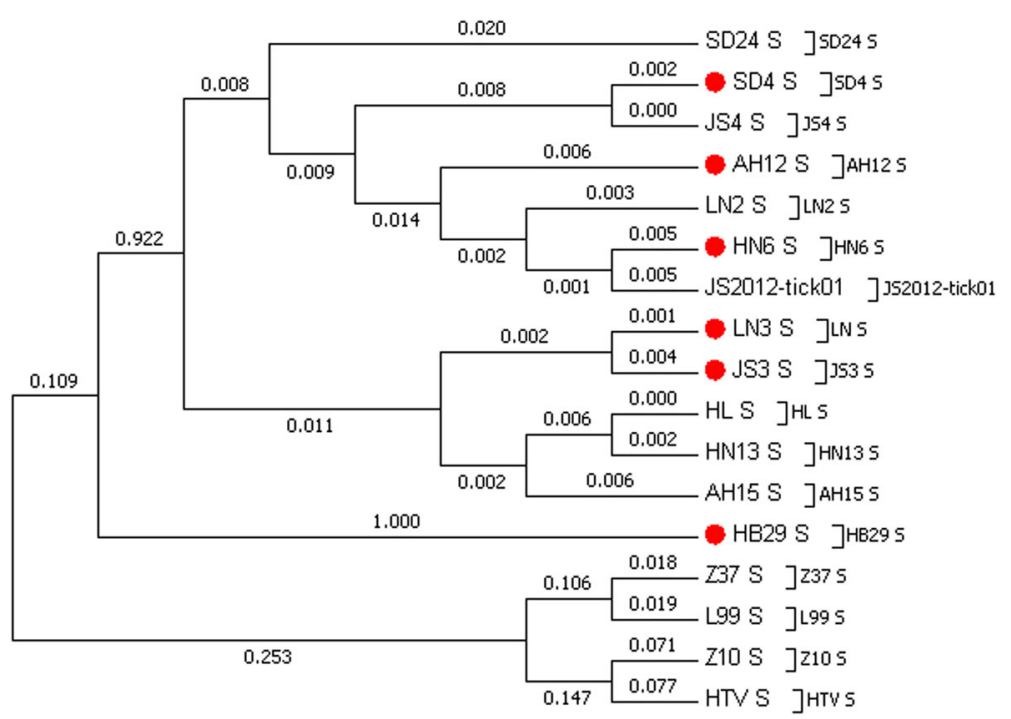

Fig. 1 The phylogenetic tree of SFTSV based on S segment. The GenBank number of each virus was listed as follow, SD24 (HM802205.1), SD4 (HM802204.1), JS4 (HQ141606.1), AH12 (HQ141591), LN2 (HQ141609.1), HN6 (HQ141597.1), JS2012-tick01 (KC473542.1), LN3 (HQ141612.1), JS3 (HQ141603), HL (KF791952.1), HN13 (HQ141600.1), AH15 (HQ141594.1), HB29 (HM745932), Z37 (AF187082.1), L99 (AF288299.1), Z10 (EF533944.1), HTV (U37768.1). Red dots indicate the strains selected for references

available for these commercial kits. In this study we established a national reference for SFTSV RNA diagnostic kits refer to the methods of other references [13-17].

\section{Methods}

\section{Viruses}

Six SFTSV strains (AH12, HN1, JS3, LN3, SD4, and HB29 isolated from Anhui, Henan, Jiangsu, Shandong, and Hubei, respectively) were provided by the $\mathrm{Na}$ tional Vaccine \& Serum Institute (Beijing, China). Japanese encephalitis virus (JEV) SA14-14-2, dengue virus (DENV) Ban18 and yellow fever virus (YFV) 17D were provided by Arbovirus Vaccine Group, National Institutes for Food and Drug Control (NIFDC). Inactivated hemorrhagic fever with renal syndrome virus (HFRSV) and tick-borne encephalitis virus (TBEV) Senzhang strain was provided by Changchun Institute of Biological Products Co., Ltd.

\section{Materials}

Nucleic acid detection kits for SFTSV (PCR-fluorescence probe techniques) were obtained from SinoMD Gene (Beijing, China) and DaAn Gene (Guangzhou, China). An RNA extraction QIAamp Viral RNA Mini Kit (cat 52904) was obtained from Qiagen (Hilden, Germany). Reverse transcriptase was purchased from Promega (Madison, WI, USA), and La Taq was purchased from Takara (Shiga, Japan).

\section{Selection of references}

Four kinds of references (positive, negative, sensitivity and accuracy) were investigated.

\section{Positive references}

References should be broad-spectrum and representative. So the phylogenetic tree of SFTSV, based on the S segment, was first draw using MEGA 6.0 (Fig. 1). To represent a range of epidemic regions and disease severities, six SFTSV strains AH12, HN1, JS3, LN3, SD4, and HB29, isolated from Anhui, Henan, Jiangsu, Shandong, and Hubei, respectively, were used as positive references.

Table 1 q-PCR results for specificity of references

\begin{tabular}{|c|c|c|c|c|c|c|}
\hline \multirow[t]{3}{*}{ Strains } & \multicolumn{6}{|c|}{ Ct value } \\
\hline & \multicolumn{2}{|c|}{ Specific primers and probe } & \multicolumn{2}{|c|}{ SinoMD kit } & \multicolumn{2}{|c|}{ DaAn kit } \\
\hline & Exp 1 & $\operatorname{Exp} 2$ & Exp 1 & $\operatorname{Exp} 2$ & Exp 1 & $\operatorname{Exp} 2$ \\
\hline $\mathrm{AH} 12$ & 22.89 & 22.84 & 24.69 & 26.50 & 20.72 & 18.60 \\
\hline HN1 & 24.05 & 23.53 & 24.96 & 26.04 & 20.91 & 20.15 \\
\hline JS3 & 25.01 & 25.26 & 25.01 & 25.50 & 21.94 & 20.84 \\
\hline LN3 & 24.29 & 23.96 & 24.26 & 22.61 & 21.26 & 20.04 \\
\hline SD4 & 24.09 & 24.05 & 26.90 & 29.86 & 21.42 & 19.27 \\
\hline HB29 & 23.68 & 22.99 & 25.30 & 23.12 & 20.44 & 18.87 \\
\hline Positive & 21.89 & 21.57 & 17.29 & 18.99 & 23.49 & 19.77 \\
\hline Negative & - & - & - & - & - & - \\
\hline
\end{tabular}

Exp experiment 


\section{a}

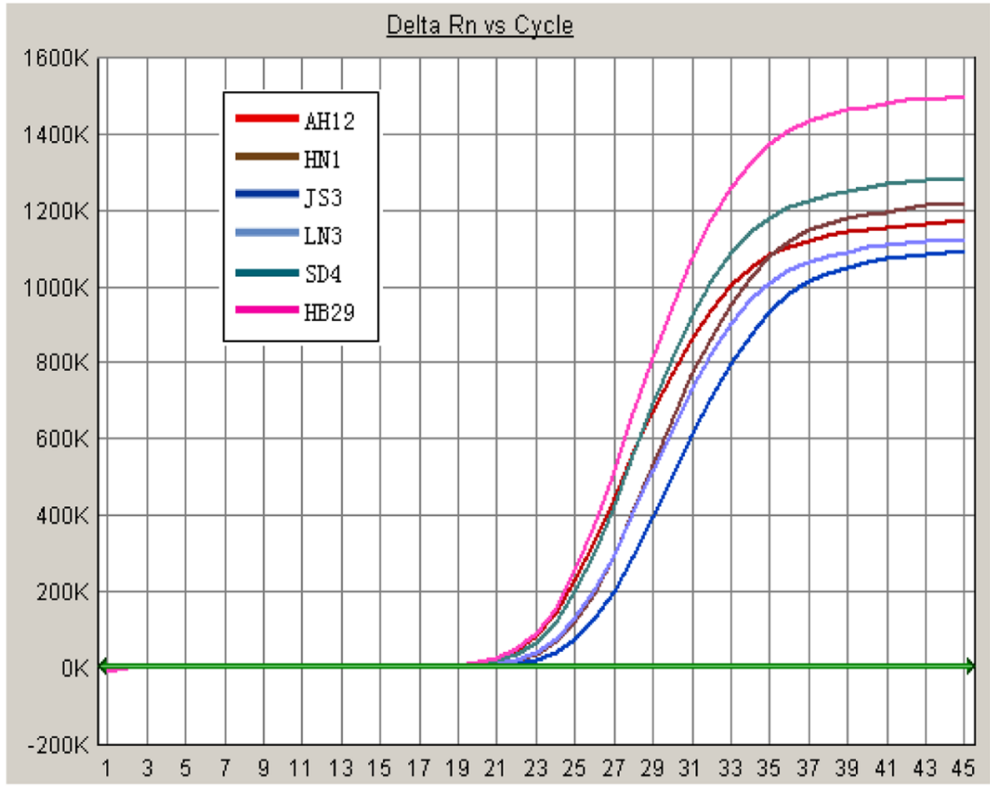

b

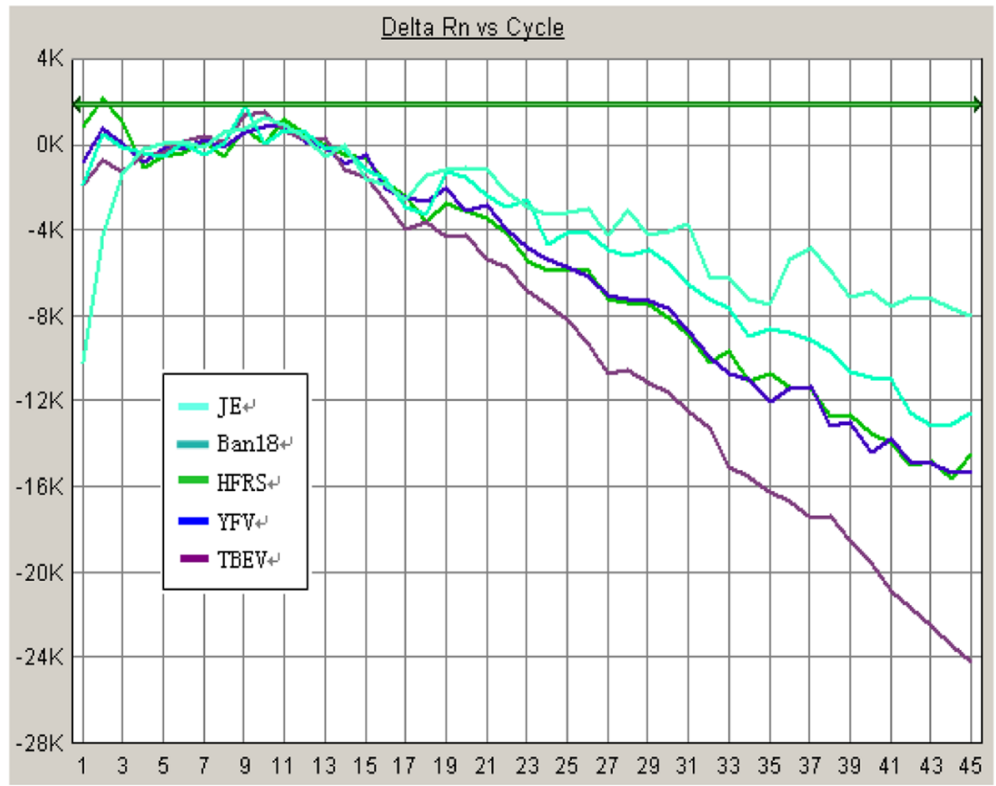

Fig. 2 q-PCR reaction curve of positive references $(\mathbf{a})$ and negative references $(\mathbf{b})$

\section{Negative references}

Five arthropod-borne or blood-borne viruses (JEV A14-14-2 strain, DENV Ban18 strain, YFV 17D strain, HFRSV L99 strain and TBEV Senzhang strain), which cause similar clinical manifestations to SFTSV infection, including fever, headache, disturbance of consciousness, convulsions, bleeding and kidney damage, meningeal irritation and paralysis, were selected as negative references to evaluate the kit specify [18-22].
The earliest isolated and extensively investigated SFTSV strain HB29 was used as references for sensitivity and accuracy.

\section{Preparation of the references}

Six SFTSV strains AH12, HN1, JS3, LN3, SD4, and HB29 were amplified. Virus titers were determined before inactivation using the cytopathogenic effect assay (CPE). JEV A14-14-2 strain, DENV Ban18 strain and YFV 17D strain was amplified in BHK 21 cells, and the 
Table 2 q-PCR results for sensitivity of reference

\begin{tabular}{|c|c|c|c|c|c|c|c|c|}
\hline \multirow[t]{3}{*}{ HB29 strain } & \multicolumn{8}{|c|}{ Ct value } \\
\hline & \multicolumn{4}{|c|}{ SinoMD kit } & \multicolumn{4}{|c|}{ DaAn kit } \\
\hline & $\operatorname{Exp} 1$ & $\operatorname{Exp} 2$ & Exp 3 & Exp 4 & $\operatorname{Exp} 1$ & $\operatorname{Exp} 2$ & Exp 3 & Exp 4 \\
\hline $\mathrm{S} 1\left(10^{5} \mathrm{U} / \mathrm{mL}\right)$ & 30.03 & 27.35 & 29.40 & 30.23 & 21.42 & 22.48 & 26.37 & 24.11 \\
\hline $\mathrm{S} 2\left(10^{4} \mathrm{U} / \mathrm{mL}\right)$ & 32.21 & 33.16 & 32.74 & 33.27 & 26.05 & 24.84 & 28.86 & 26.69 \\
\hline $\mathrm{S} 3\left(10^{3} \mathrm{U} / \mathrm{mL}\right)$ & 37.07 & 34.04 & 35.60 & 36.19 & 28.28 & 28.32 & 30.75 & 28.13 \\
\hline $\mathrm{S} 4\left(10^{2} \mathrm{U} / \mathrm{mL}\right)$ & - & 37.36 & - & - & 32.20 & 29.46 & 31.79 & 31.08 \\
\hline $\mathrm{S} 5(10 \mathrm{U} / \mathrm{mL})$ & - & - & - & - & - & 32.37 & 32.06 & 31.17 \\
\hline Positive & 17.59 & 16.75 & 17.84 & 19.07 & 19.77 & 23.49 & 20.69 & 20.00 \\
\hline Negative & - & - & - & - & - & - & - & - \\
\hline
\end{tabular}

titers were determined using a CPE method. HFRSV L99 strain and TBEV Senzhang strain were provided by Changchun Institute of Biological Products. All viruses were inactivated using formaldehyde $(1: 1000)$ at $37{ }^{\circ} \mathrm{C}$ for $24 \mathrm{~h}$ and stored in $-80{ }^{\circ} \mathrm{C}$ for use.

\section{Confirmation of the references}

\section{Sequence confirmation of the references}

The S gene represents a conserved region of the SFTSV genome [3]. The whole genome of JEV is conserved [23]. The NS1 gene represents a conserved region of DENV [24]. The S gene represents a conserved region of HFRSV [25]. 3' UTR is the conserved region of YFV [21]. 5'UTR is the conserved region of TBEV [22]. The specific primers for the conserved region of each virus were designed using DNAMan (Lynnon, San Ramon, CA, USA).

Virus RNA genome was extracted using QIAamp Viral RNA Mini Kit and then reverse transcribed into cDNA. The cDNA was used as template for PCR in a total volume of $50 \mu \mathrm{L}$ (LA Taq, $0.2 \mu \mathrm{L}$, Buffer $5 \mu \mathrm{L}$, dNTP $4 \mu \mathrm{L}$, cDNA template $2 \mu \mathrm{L}$, primers $2 \mu \mathrm{L}$ and $\mathrm{ddH}_{2} \mathrm{O} 37 \mu \mathrm{L}$ ) using the following procedures: denaturation at $94{ }^{\circ} \mathrm{C}$ for $2 \mathrm{~min} ; 30$ cycles of $94^{\circ} \mathrm{C}$ for $30 \mathrm{~s}, 56^{\circ} \mathrm{C}$ for $30 \mathrm{~s}, 72^{\circ} \mathrm{C}$ for $30 \mathrm{~s}$, and finally extension at $72{ }^{\circ} \mathrm{C}$ for $5 \mathrm{~min}$. The PCR products were confirmed by sequencing (Invitrogen, Carlsbad, CA, USA).

\section{Confirmation by quantitative PCR ( $q-P C R$ )}

Specific primers and probe was synthesized for $S$ gene of SFTSV.

\section{SFTSVF: 5'GGGTCCCTGAAGGAGTTGTAAA3'}

SFTSVR: 5'TGCCTTCACCAAGACTATCAATGT3', SFTSVP: FAM-TTCTGTCTTGCTGGCTCCGCGCBHQ1

References were quantified using specific primers and probes, SFTSV nucleic acid detection kits (PCR-fluorescence probe techniques) from SinoMD Gene, and DaAn Gene. The reaction system for specific primers and probes were: $0.1 \mu \mathrm{L}$ LA Taq, $2.5 \mu \mathrm{L}$ reaction buffer, $2 \mu \mathrm{L}$ dNTP, $5 \mu \mathrm{L}$ template, $2 \mu \mathrm{L}$ primes, $1 \mu \mathrm{L}$ probe, and $12.4 \mu \mathrm{L}$ $\mathrm{ddH}_{2} \mathrm{O}$. The q-PCR procedure was as follows: denaturation at $94{ }^{\circ} \mathrm{C}$ for $10 \mathrm{~min} ; 40$ cycles of $94{ }^{\circ} \mathrm{C}$ for $30 \mathrm{~s}, 56{ }^{\circ} \mathrm{C}$ for 30s. The reaction system for the SinoMD kit was: SFTSV PCR buffer $12.5 \mu \mathrm{L}$, SFTSV primers and probe mixture $2.5 \mu \mathrm{L}$, SFTSV internal template $1.0 \mu \mathrm{L}$, DEPC $\mathrm{H}_{2} \mathrm{O} 4.0 \mu \mathrm{L}$, template $5.0 \mu \mathrm{L}$. The q-PCR procedure was as follows: $45^{\circ} \mathrm{C}$ for $15 \mathrm{~min}, 94^{\circ} \mathrm{C}$ for $5 \mathrm{~min}$; 40 cycles of $94{ }^{\circ} \mathrm{C}$ for $15 \mathrm{~s}, 60{ }^{\circ} \mathrm{C}$ for $35 \mathrm{~s} ; 25^{\circ} \mathrm{C}$ for $1 \mathrm{~min}$. The reaction system for the DaAn kit was: SFTSV reaction buffer A $17 \mu \mathrm{L}$, SFTSV reaction buffer B $3 \mu \mathrm{L}$, template, $5 \mu \mathrm{L}$. The q-PCR procedure was as follows: $50{ }^{\circ} \mathrm{C}$ for $15 \mathrm{~min}, 94{ }^{\circ} \mathrm{C}$ for $15 \mathrm{~min}$; 45 cycles of $94^{\circ} \mathrm{C}$ for $15 \mathrm{~s}, 55^{\circ} \mathrm{C}$ for $45 \mathrm{~s}$.

\section{Confirmation of sensitivity}

The extensively investigated SFTSV strain HB29 was used as a reference for sensitivity testing. First, the recombinant plasmid containing the conserved $\mathrm{S}$ gene pMD18-TS was constructed, serial diluted 1:10 and then used to establish a standard curve. $4.83 \times 10^{6}$ copies $/ \mathrm{mL}$ of SFTSV HB29 was defined as $10^{6} \mathrm{U} / \mathrm{mL}$. Ten-fold serial dilutions of SFTSV HB29 $\left(10^{5} \mathrm{U} / \mathrm{mL}, 10^{4} \mathrm{U} / \mathrm{mL}, 10^{3}\right.$ $\mathrm{U} / \mathrm{mL}, 10^{2} \mathrm{U} / \mathrm{mL}, 10 \mathrm{U} / \mathrm{mL}$ ) were used as sensitivity references and labeled S1-S5. The lowest detection limit of the reference was assessed using SinoMD kit and DaAn kit for 4 times.

\section{Confirmation of accuracy}

The reference $\left(10^{4} \mathrm{U} / \mathrm{mL}\right.$ (S3) SFTSV HB29) was detected using the SinoMD and DaAn kits for 10 times and the coefficient of variation $(\mathrm{CV})$ of each $\mathrm{Ct}$ was calculated and defined as the accuracy of the reference.

\section{Stability of the references}

Three sets of references stored at $-70{ }^{\circ} \mathrm{C}$ were randomly selected. One set was placed at $37{ }^{\circ} \mathrm{C}$ with $60-80 \%$ relative humidity for 8 days, one at room temperature with $20-50 \%$ relative humidity for 14 days, and one at $-70{ }^{\circ} \mathrm{C}$ for 8 months. The stability of these references was determined using the detection kits.

The references stored at $-70{ }^{\circ} \mathrm{C}$ were subjected to $3 \mathrm{cy}$ cles of freeze-thaw, then nucleic acid detection was performed to determine the effect of freeze-thaw treatment.

\section{Collaborative calibration of the references}

According to the Program, Protocol, Standard Operating Procedure of Collaborative Calibration approved by the National Administrative Committee for Certified Reference Materials, and unified original experimental record, the collaborative calibration was completed by the Second Group for in vitro Diagnostics of NIFDC, Arbovirus Vaccine Group of NIFDC and DaAn Gene Co. Ltd. 


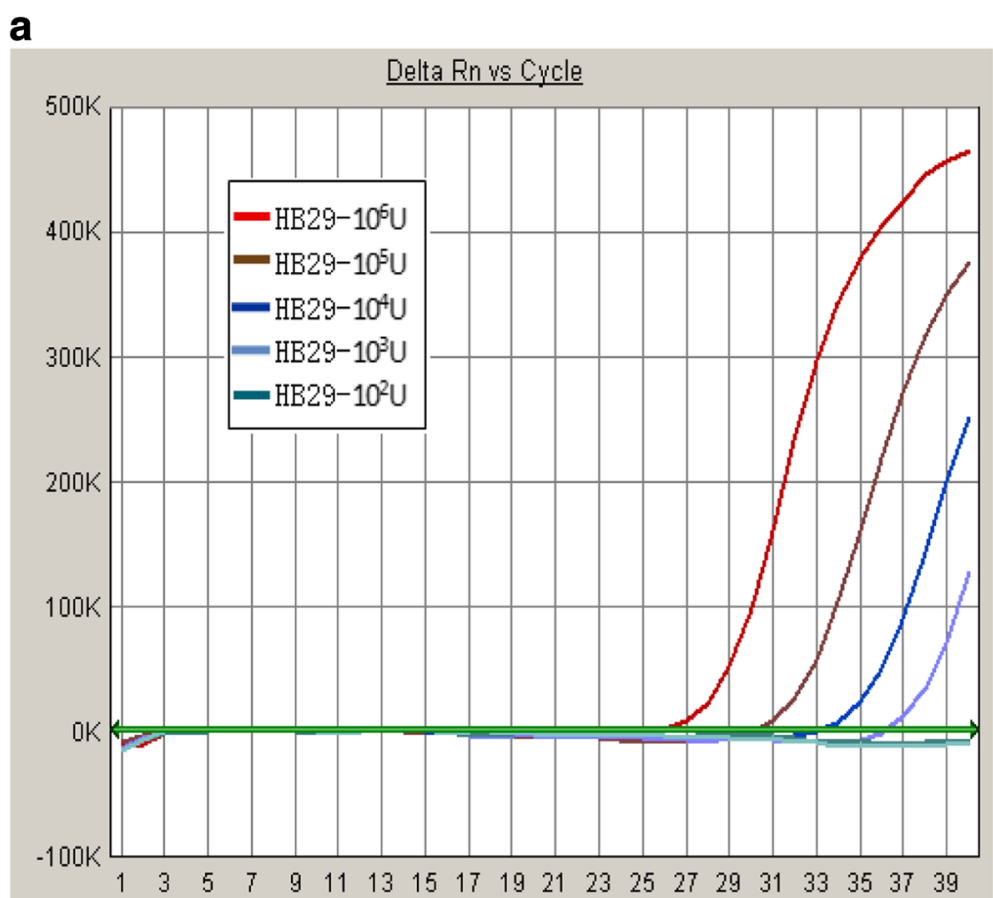

b

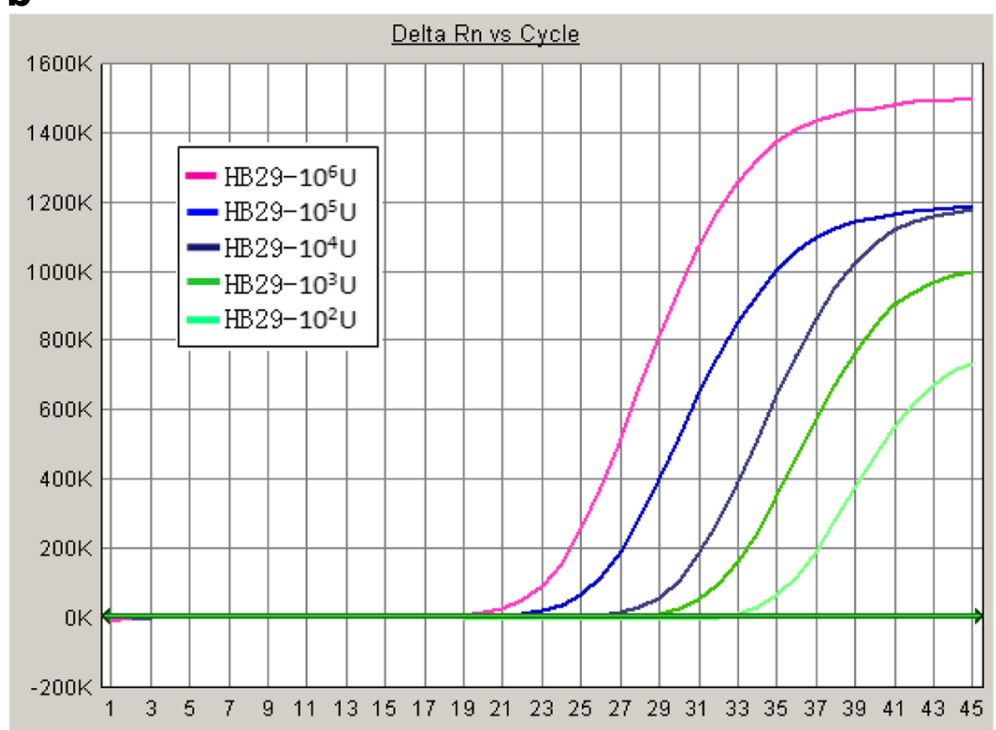

Fig. 3 q-PCR reaction curve of sensitivity reference using SinoMD kit (a) and DaAn kit (b)

\section{Statistical analysis}

Statistical analysis was performed using SAS 9.1 (Raleigh, NC, USA), and means are presented. $T$ test was used to analyze the stability in each treatment groups. A $p$ value $<0.05$ was considered to indicate statistical significance.

\section{Results}

Preparation of the references

Using the CPE method, the titer of SFTSV ranged from 6.8 to $8.3 \lg \mathrm{CCID}_{50} / \mathrm{mL}$, the titers of the JEV A14-14-2 strain, DV Ban18 strain and YFV 17D strain were $5.56 \mathrm{lg}$ $\mathrm{PFU} / \mathrm{mL}, 5.40 \mathrm{lg} \mathrm{PFU} / \mathrm{mL}$ and $6.09 \mathrm{lg} \mathrm{PFU} / \mathrm{mL}$, respectively. The titers of the provided HFRSV L99 strain and TBEV Senzhang strain were $7.3 \mathrm{lg} \mathrm{CCID}_{50} / \mathrm{mL}$ and $8.0 \mathrm{lg}$ $\mathrm{LD}_{50} / \mathrm{mL}$, respectively.

\section{Specificity of the references}

Sequencing of these 6 positive and 5 negative references indicated that all conserved virus genes or genomes (S gene of SFTSV, whole genome of JEV, NS1 gene of, S gene of HFRSV, 3' UTR of YFV and 
Table 3 q-PCR results for accuracy of reference

\begin{tabular}{|c|c|c|c|c|}
\hline \multirow[t]{3}{*}{ References } & \multicolumn{4}{|c|}{ Ct value } \\
\hline & \multicolumn{2}{|c|}{ SinoMD kit } & \multicolumn{2}{|c|}{ DaAn kit } \\
\hline & Exp 1 & Exp 2 & Exp 1 & $\operatorname{Exp} 2$ \\
\hline R1 & 33.27 & 33.80 & 26.05 & 27.47 \\
\hline R2 & 34.19 & 34.98 & 27.63 & 27.08 \\
\hline R3 & 30.72 & 33.10 & 27.67 & 26.22 \\
\hline R4 & 31.24 & 33.03 & 27.38 & 28.15 \\
\hline R5 & 32.75 & 36.36 & 26.26 & 27.12 \\
\hline R6 & 32.19 & 34.00 & 26.14 & 25.56 \\
\hline R7 & 31.85 & 33.34 & 26.11 & 25.67 \\
\hline R8 & 32.62 & 33.93 & 25.29 & 24.84 \\
\hline R9 & 34.43 & 32.74 & 27.34 & 28.03 \\
\hline R10 & 30.90 & 34.18 & 26.89 & 25.09 \\
\hline SD & 1.29 & 1.07 & 0.81 & 1.21 \\
\hline Average & 32.42 & 33.95 & 26.68 & 26.52 \\
\hline CV (\%) & 3.98 & 3.16 & 3.05 & 4.55 \\
\hline
\end{tabular}

Exp experiment, R1-R10 repeat 1-10, SD standard deviation, $C V$ coefficient of variation

5'UTR of TBEV) shared 99\% homology with genes from the same or similar virus strains.

Next these positive and negative references were applied for q-PCR using SFTSV specific primers and probes, and kits from SinoMD and DaAn gene. The positive $\mathrm{Ct}$ value was defined as less than 35 for specific primers and probes, and less than 37 for the two kits according to the manufacturers' protocol. The Ct values of 6 positive references were all less than 35, with typical $\mathrm{S}$ curves for specific primers and probes as well as two commercial kits (Table 1, Fig. 2a). No typical $\mathrm{S}$ curve was observed in five negative samples (Fig. 2b), so no Ct values were given. Our results indicated that these positive and negative references were highly specific and accurate.

\section{Sensitivity of the references}

The recombinant plasmid pMD18-TS for standard curve ranged from $2.01 \times 10^{12}$ copies $/ \mathrm{mL}$ to $2.01 \times 10^{4}$ copies $/ \mathrm{mL}$ in ten-fold dilutions. The sensitivity reference SFTSV HB29 strain was used at $4.83 \times 10^{6}$ copies $/ \mathrm{mL}$, serially diluted 1:10 five types (S1-S5), and detected using two commercial kits. As shown in Table 2, the detection limit of the SinoMD kit was S3 with $10^{3} \mathrm{U} / \mathrm{mL}$ virus, while the detection limit of the DaAn kit was S4 with $10^{2} \mathrm{U} / \mathrm{mL}$ virus. Although S5 with $10 \mathrm{U} / \mathrm{mL}$ virus can be detected using the DaAn kit in 3 of 4 times, the $\mathrm{Ct}$ value and dilution did not have a linear relationship. The detection limit was still S4 with $10^{2} \mathrm{U} / \mathrm{mL}$ virus. The $\mathrm{q}-\mathrm{PCR}$ reaction curves of sensitivity reference are shown in (Fig. 3a and $3 \mathrm{~b})$.

The virus titer in the serum of patients with SFTSV infection is reported to usually range between $10^{2}$ and $10^{8}$ copies $/ \mathrm{mL}$ [26-29], so to be clinically useful a reference concentration of $10^{2} \mathrm{U} / \mathrm{mL}$ must be detectable by commercial kits.

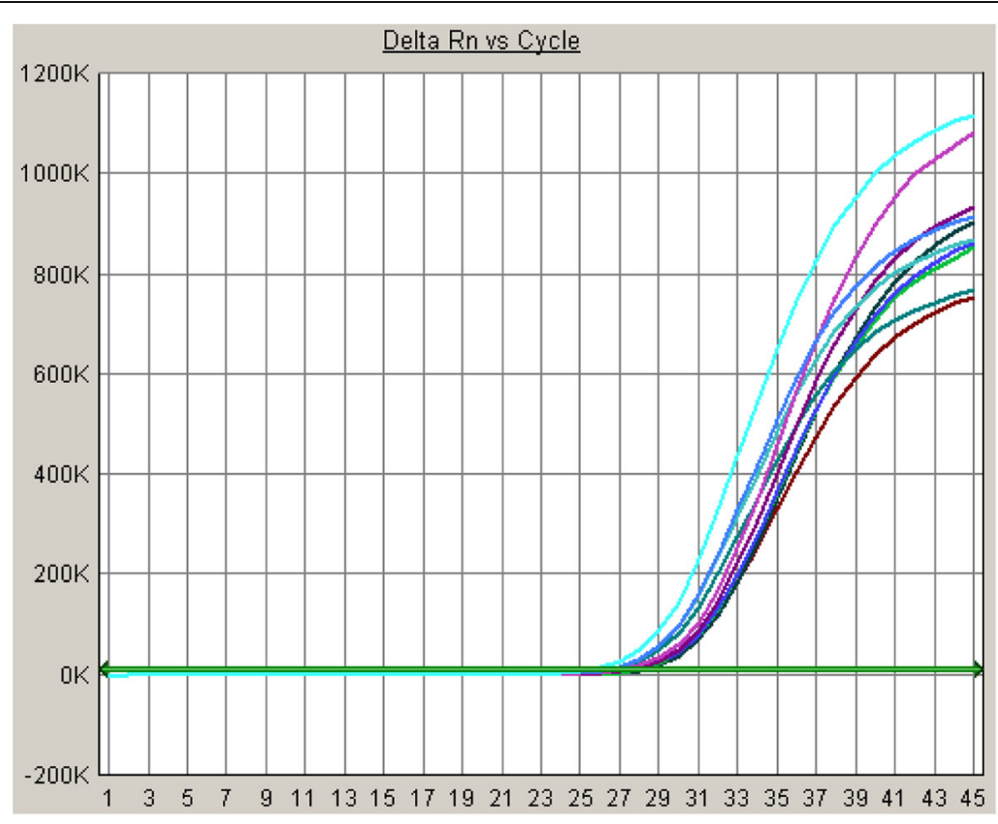

Fig. 4 q-PCR reaction curve of accuracy for reference 
Table 4 q-PCR results for stability of reference in different storage conditions

\begin{tabular}{|c|c|c|c|c|c|}
\hline \multirow[t]{2}{*}{ References } & & \multicolumn{3}{|l|}{ Ct value } & \multirow[t]{2}{*}{ Normal value } \\
\hline & & $37^{\circ} \mathrm{C}$ for 8 days & Room temperature for 14 days & $-70{ }^{\circ} \mathrm{C}$ for 8 months & \\
\hline \multirow[t]{6}{*}{ Positive } & $\mathrm{P} 1(\mathrm{AH} 12)$ & 18.02 & 22.81 & 22.84 & 18.60 \\
\hline & P2 (HN1) & 18.49 & 24.02 & 23.53 & 20.15 \\
\hline & P3 (JS3) & 24.83 & 25.07 & 25.26 & 20.84 \\
\hline & P4 (LN3) & 18.80 & 24.52 & 23.96 & 20.04 \\
\hline & P5 (SD4) & 22.41 & 23.88 & 24.05 & 19.27 \\
\hline & P6 (HB29) & 17.92 & 22.35 & 22.99 & 18.87 \\
\hline \multirow[t]{5}{*}{ Sensitivity } & S1 (105U) & 20.20 & 26.69 & 25.51 & 21.42 \\
\hline & S2 (104U) & 23.99 & 30.03 & 27.46 & 26.05 \\
\hline & S3 (103U) & 27.40 & 32.23 & 30.78 & 28.28 \\
\hline & S4 (102U) & 35.29 & 35.54 & 31.08 & 32.20 \\
\hline & S5 (10U) & - & 37.23 & 32.68 & - \\
\hline \multirow[t]{13}{*}{ Accuracy } & R1 & 27.50 & 29.87 & 27.77 & 27.47 \\
\hline & R2 & 24.56 & 29.78 & 28.08 & 27.08 \\
\hline & R3 & 27.50 & 29.21 & 27.89 & 26.22 \\
\hline & R4 & 24.30 & 30.61 & 27.89 & 28.15 \\
\hline & R5 & 24.27 & 30.04 & 27.63 & 27.12 \\
\hline & R6 & 23.99 & 28.70 & 27.85 & 25.56 \\
\hline & R7 & 25.09 & 30.03 & 27.81 & 25.67 \\
\hline & R8 & 25.11 & 31.76 & 28.01 & 24.84 \\
\hline & R9 & 25.01 & 31.39 & 27.60 & 28.03 \\
\hline & R10 & 25.06 & 31.16 & 27.37 & 25.09 \\
\hline & SD & 1.26 & 0.97 & 0.21 & 1.21 \\
\hline & Average & 25.24 & 30.26 & 27.79 & 26.52 \\
\hline & CV & $5.00 \%$ & $3.20 \%$ & $0.75 \%$ & $4.55 \%$ \\
\hline
\end{tabular}

\section{Repeatability of the references}

To evaluate the repeatability of the accuracy reference, a sample containing $10^{4} \mathrm{U} / \mathrm{mL}$ (S3) SFTSV HB29 was detected using the SinoMD and DaAn kits in five independent experiments including two duplicates each. As shown in Table 3, the SinoMD kit CV of $\mathrm{Ct}$ was 3.98 and $3.16 \%$, while the DaAn kit CV of $\mathrm{Ct}$ was 3.04 and $4.55 \%$. So the $\mathrm{CV}$ of $\mathrm{Ct}$ for this accuracy reference was determined as less than $5 \%$. See (Fig. 4) for q-PCR reaction curve of accuracy for reference.

\section{Stability of all references}

The appearance of the references was not altered by storage at $37{ }^{\circ} \mathrm{C}$ for 8 days, and at room temperature with $20-50 \%$ for 14 days, or at $-70{ }^{\circ} \mathrm{C}$ for 8 months. All references appeared to be transparent liquids with no turbidity or precipitation. When these references were subjected to q-PCR with specific primers, treated positive references were positive, while all treated negative references were negative, without typical S curves or $\mathrm{Ct}$ values higher than 37 . The detection limits of all treated sensitivity references were $10^{2} \mathrm{U} / \mathrm{mL}$ virus and the $\mathrm{CV}$ values of $\mathrm{Ct}$ for all treated accuracy references were less than 5\% (Table 4, Fig. 5a, 5b and 5c).

The references were subjected to 3 cycles of freezethaw treatment and after each cycle tested using q-PCR. The accuracy reference $\mathrm{CV}$ values of $\mathrm{Ct}$ did not differ between the three cycles (Tables 5, P>0.05). All these data suggest that all references exhibit good stability to temperature.

\section{Calibration of the references}

Calibration of the references is described in Table 6. In three independent laboratories the positive rate of positive references and negative rate of negative references were all $100 \%$. The detection limit of the sensitivity reference was $10^{2} \mathrm{U} / \mathrm{mL}$. The $\mathrm{CV}$ of the accuracy reference ranged from 0.45 to $4.55 \%$, which were all less than $5 \%$. 


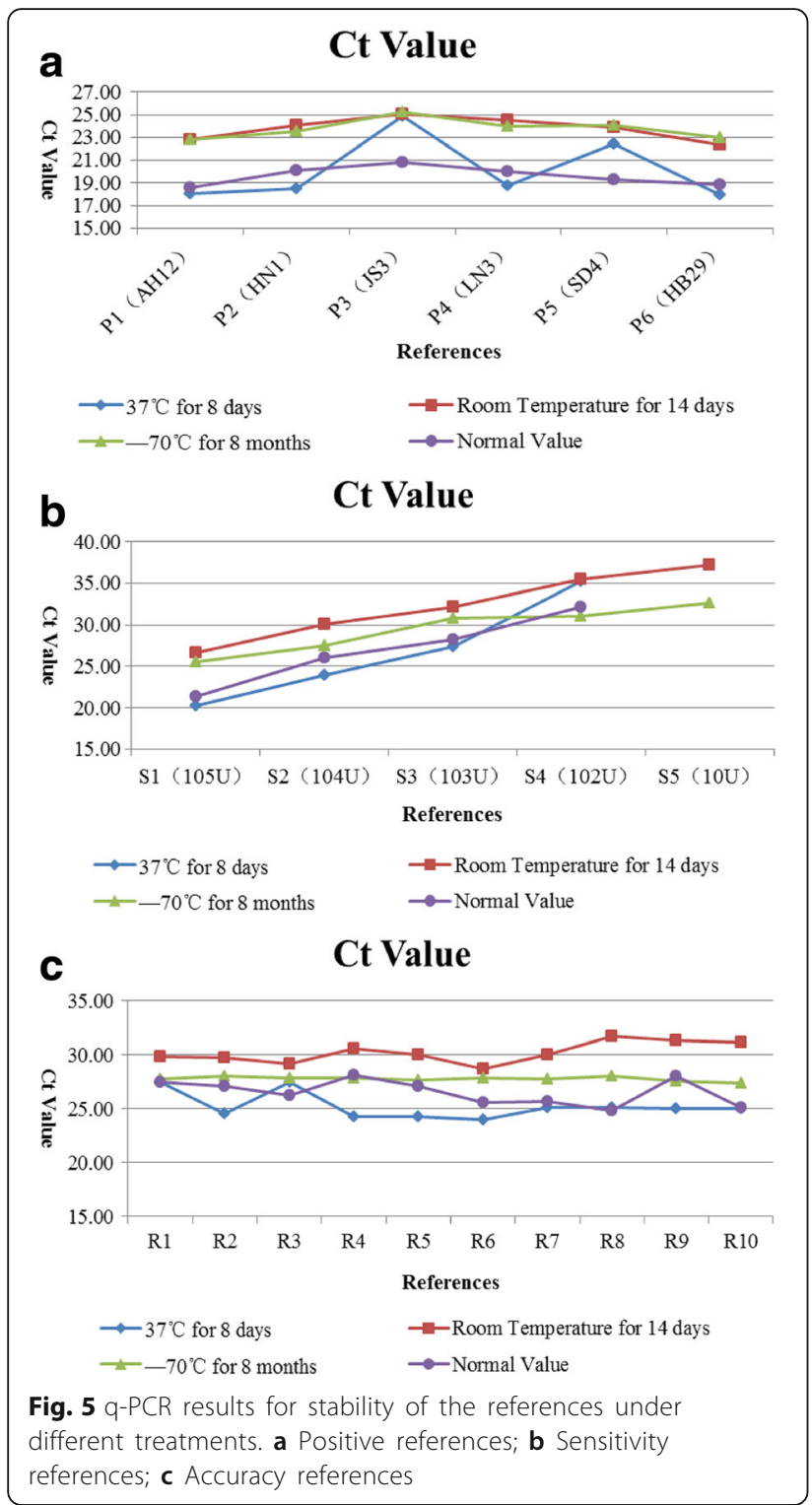

\section{Discussion}

SFTS caused by SFTSV infection was first emerged in China in 2009 [3], followed by reports from other Asian countries. At present no effective therapies or vaccines are available, and SFTS is associated with high rates of fatality $[1,5,30]$. In addition to reducing rates of tick bite, early diagnosis and treatment are important. Hence many research institutes and companies are developing diagnostic kit for SFTSV based on the detection of virus genome using q-PCR. However, no references are yet available to control the quantity of these kits. Thus in this study we established national references that allow specific, sensitive and accurate detection of the SFTSV genome.
Table 5 q-PCR results for stability of the references subjected to freeze-thraw

\begin{tabular}{|c|c|c|c|}
\hline \multirow[t]{2}{*}{ Reference } & \multicolumn{3}{|l|}{ Ct value } \\
\hline & First F-T & Second F-T & Third F-T \\
\hline \multirow[t]{3}{*}{ HB29 strain } & 25.49 & 26.23 & 27.31 \\
\hline & 26.29 & 25.80 & 26.58 \\
\hline & 26.10 & 26.28 & 25.80 \\
\hline Average & 25.96 & 26.10 & 26.56 \\
\hline \multirow[t]{4}{*}{ HB29 strain at 1:100 } & 33.27 & 31.85 & 34.43 \\
\hline & 34.19 & 32.62 & 30.90 \\
\hline & 30.72 & 32.75 & 33.48 \\
\hline & 31.24 & 32.19 & 33.00 \\
\hline Average & 32.36 & 32.35 & 32.95 \\
\hline
\end{tabular}

F-T freeze-thaw

When establishing reference standards, the references should be represent a broad-spectrum of relevant viruses [31]. In 2007, the first SFTS case in China was reported in Henan Province, and since cases have been reported in Shandong, Hubei, Anhui, Jiangsu, and Niaoning [1]. Thus we chose viruses from these regions to use as the reference strains. The severity of the disease caused by these virus strains also should be considered. We drew a phylogenetic tree based on $\mathrm{S}$ segment and selected six representative SFTSV strains, AH12, HN1, JS3, LN3, SD4, and HB29, isolated from Anhui, Henan, Jiangsu, Liaoning, Shandong, Hubei respectively, as positive references. When selecting negative references, HFRSV was chosen because of the similar structure and family to SFTSV [32]. JEV, DenV, YFV and TBEV were chosen as they cause similar clinical symptoms and are transmitted by arthropods or blood, like SFTSV [18-22]. Before establishing references, conserved regions of these 11 viruses were amplified using specific primers and sequenced. Then q-PCR was used to detect the specificity and accuracy of positive and negative references.

When selecting sensitive and accurate references, the earliest identified and extensively studied HB29 strain was chosen. The serial dilution method was used to determine the detection limit of the reference. Through collaborative calibration by three labs, the detection limit was set as $10^{2} \mathrm{U} / \mathrm{mL}$, as SFTSV infection is reported to cause titers of $10^{2}-10^{8} \mathrm{copies} / \mathrm{mL}$ in the serum [26-29]. The CVs of $\mathrm{Ct}$ were all less than $5 \%$, indicating acceptable accuracy.

We also investigated the capacity of the references to withstand freeze-thaw and conditions typical of storage, transportation and application, as previously reported [33]. Storage at room temperature, $37{ }^{\circ} \mathrm{C}$ and several freeze-thaw cycles did not alter the specificity, accuracy, and sensitivity of the references, indicating high stability. 
Table 6 Calibration of the references

\begin{tabular}{|c|c|c|c|c|c|}
\hline Labs & Exp & Positive coincidence rate & Negative coincidence rate & $\begin{array}{l}\text { Sensitivity } \\
\left(10^{2} \mathrm{U} / \mathrm{mL}\right)\end{array}$ & Accuracy (CV) \\
\hline \multirow[t]{4}{*}{ Second group for in vitro diagnostics of NIFDC } & 1 & $100 \%$ & $100 \%$ & Detected & $3.49 \%$ \\
\hline & 2 & $100 \%$ & $100 \%$ & Detected & $0.45 \%$ \\
\hline & 3 & $100 \%$ & $100 \%$ & Detected & $3.80 \%$ \\
\hline & Average & $100 \%$ & $100 \%$ & Detected & $2.58 \%$ \\
\hline \multirow[t]{5}{*}{ Arbovirus vaccine group of NIFDC } & 1 & $100 \%$ & $100 \%$ & Detected & $3.98 \%$ \\
\hline & 2 & $100 \%$ & $100 \%$ & Detected & $3.16 \%$ \\
\hline & 3 & $100 \%$ & $100 \%$ & Detected & $3.05 \%$ \\
\hline & 4 & $100 \%$ & $100 \%$ & Detected & $4.55 \%$ \\
\hline & Average & $100 \%$ & $100 \%$ & Detected & $3.69 \%$ \\
\hline \multirow[t]{6}{*}{ DaAn gene Co. Ltd } & 1 & $100 \%$ & $100 \%$ & Detected & $1.97 \%$ \\
\hline & 2 & $100 \%$ & $100 \%$ & Detected & $1.53 \%$ \\
\hline & 3 & $100 \%$ & $100 \%$ & Detected & $0.56 \%$ \\
\hline & 4 & $100 \%$ & $100 \%$ & Detected & $1.44 \%$ \\
\hline & 5 & $100 \%$ & $100 \%$ & Detected & $1.19 \%$ \\
\hline & Average & $100 \%$ & $100 \%$ & Detected & $1.34 \%$ \\
\hline
\end{tabular}

\section{Conclusions}

The national reference had been established successfully and proved good accuracy, high specificity, sensitivity and stability. It means that the reference will be widely used in the quality control of the similar commercial SFTSV diagnostic kits and guarantee their effectiveness, thus more SFTSV infection can be diagnosed rapidly and the targeted prevention and control measures will be developed.

\section{Additional file}

Additional file 1: The q-PCR results and phylogenetic tree of SFTSV study. (RAR $2243 \mathrm{~kb}$ )

\section{Acknowledgement}

We thank Xunian Gao from DaAn Gene Co. Ltd., and Yuliang Song from Beijing SinoMD Gene Detection Co. Ltd. for their supports and help. Thanks for their technology help on the design of the study and the diagnose kit they supplied.

\section{Funding}

Not applicable.

\section{Availability of data and materials}

For the Additional file 1, you can see them in the attachment. The q-PCR result was produced on ABI 7500 real time q-PCR instrument. The phylogenetic tree of SFTSV was made by MEGA 6.0 software.

\section{Authors' contributions}

$\mathrm{XL}$ carried out the trial and data analysis in the whole research and drafted the manuscript. LW contacted the collaborative calibration of the references, participated in the statistical analysis and helped to draft the manuscript. DB participated in the design and coordination of the research. YL conceived of the study, guided the trial and helped to draft the manuscript. All authors read and approved the final manuscript.

\section{Authors' information}

$\mathrm{XL}$, master degree, Key Laboratory of the Ministry of Health for Research on Quality and Standardization of Biotech Products, National Institutes for Food and Drug Control, Beijing, 100050, People's Republic of China.

LW, master degree, Key Laboratory of the Ministry of Health for Research on Quality and Standardization of Biotech Products, National Institutes for Food and Drug Control, Beijing, 100050, People's Republic of China.

$\mathrm{DB}$, superintendent of diagnostic reagent management, Key Laboratory of the Ministry of Health for Research on Quality and Standardization of Biotech Products, National Institutes for Food and Drug Control, Beijing, 100050, People's Republic of China.

$\mathrm{YL}$, professor, director of arbovirus vaccine department, Key Laboratory of the Ministry of Health for Research on Quality and Standardization of Biotech Products, National Institutes for Food and Drug Control, Beijing, 100050, People's Republic of China. E-mail: lyhchengdu@163.com.

\section{Competing interests}

The authors declare that they have no competing interests.

\section{Consent for publication}

Not applicable.

Ethics approval and consent to participate Not applicable.

Received: 18 October 2016 Accepted: 12 January 2017

Published online: 16 February 2017

\section{References}

1. Liu Q, He B, Huang SY, Wei F, Zhu XQ. Severe fever with thrombocytopenia syndrome, an emerging tick-borne zoonosis. Lancet Infect Dis. 2014;14(8):763-72.

2. Li DX. Fever with thrombocytopenia associated with a Novel Bunyavirus in China. Chin J Exp Clin Virol. 2011;25(2):81-4

3. Yu XJ, Liang MF, Zhang SY, et al. Fever with thrombocytopenia associated with a novel bunyavirus in China. N Engl J Med. 2011;364(16):1523-32.

4. Denic S, Janbeih J, Nair S, Conca W, Tariq WU, Al-Salam S. Acute thrombocytopenia, leucopenia, and multiorgan dysfunction: the first case of SFTS bunyavirus outside China? Case Rep Infect Dis. 2011;2011:204056.

5. Kim KH, Yi J, Kim G, et al. Severe fever with thrombocytopenia syndrome, South Korea, 2012. Emerg Infect Dis. 2013;19(11):1892-4. 
6. Takahashi T, Maeda K, Suzuki T, et al. The first identification and retrospective study of Severe Fever with Thrombocytopenia Syndrome in Japan. J Infect Dis. 2014;209(6):816-27.

7. Ding F, Zhang W, Wang $L$, et al. Epidemiologic features of sever fever with thrombocytopenia syndrome in China, 2011-2012. Clin Infect Dis. 2013; 56(11):1682-3.

8. Li Y, Yu HJ, et al. Epidemiological analysis on severe fever with thrombocytopenia syndrome under the national surveillance data from 2011 to 2014, China. Chin J Epidemiol. 2015;36(6):598-602.

9. Lei XY, Liu MM, Yu XJ. Severe fever with thrombocytopenia syndrome and its pathogen SFTSV. Microbes Infect/Institut Pasteur. 2015;17(2):149-54.

10. Yoshikawa T, Fukushi $\mathrm{S}$, Tani $\mathrm{H}$, et al. Sensitive and specific PCR systems for detection of both Chinese and Japanese severe fever with thrombocytopenia syndrome virus strains and prediction of patient survival based on viral load. J Clin Microbiol. 2014:52(9):3325-33.

11. Wang X, Zhang Q, Hao F, et al. Development of a colloidal gold kit for the diagnosis of severe fever with thrombocytopenia syndrome virus infection. Biomed Res Int. 2014;2014:530621.

12. Li Z, Cui L, Zhou M, et al. Development and application of a one-step realtime RT-PCR using a minor-groove-binding probe for the detection of a novel bunyavirus in clinical specimens. J Med Virol. 2013:85(2):370-7.

13. Li C, Xu K, Hashem A, et al. Collaborative studies on the development of national reference standards for potency determination of H7N9 influenza vaccine. Hum Vaccin Immunother. 2015;11(6):1351-6.

14. Liang Z, Mao Q, Gao Q, et al. Establishing China's national standards of antigen content and neutralizing antibody responses for evaluation of enterovirus 71 (EV71) vaccines. Vaccine. 2011;29(52):9668-74.

15. Xu SH, Song AJ, Nie JH, et al. Preparation of national reference panel of HIV1 RNA for NAT donor screening. Chin J Biologicals. 2009;22(2):174-7.

16. Zhang CT, Song AJ, Li XH, Li J, Wang YC. Establishment of the reference panel for HIV RNA. Chin J Exp Clin Virol. 2004;18(4):321-4.

17. Qi Z, Zhou C, Yang Z, Zhang S, Gu J, Li H. Preparation and preliminary application of the third generation of national reference for anti-HCV diagnostic kits. Chin J Biologicals. 1999;12(2):103-5.

18. Solomon T, Vaughn DW. Pathogenesis and clinical features of Japanese encephalitis and West Nile virus infections. Curr Top Microbiol Immunol. 2002;267:171-94.

19. Zhao W, Yang PY. Dengue virus infection: epidemiology, clinical manifestation, diagnosis and prevention. Bull Acad Military Med Sci. 2000;24:57-61.

20. Shi J. Research progress in hemorrhagic fever with renal syndrome epidemiology in China. Chin J Zoonoses. 2007;23:296-8.

21. Li J, Yu YX, Dong GM, et al. Completed sequences analysis on the Chinese attenuated yellow fever 17D vaccine strain and the WHO standard yellow fever 17D vaccine strain. Chin J Vaccines Immunization. 2009:15:145-51.

22. Ma XY, Si BY, et al. Nucleotide sequence of the polyprotein of the Tick-borne encephalitis virus senzhang strain isolated in China. Virol Sin. 2003;18:322-5.

23. Nitayaphan S, Grant JA, Chang GJ, Trent DW. Nucleotide sequence of the virulent SA-14 strain of Japanese encephalitis virus and its attenuated vaccine derivative, SA-14-14-2. Virology. 1990;177(2):541-52.

24. Zhang $L$, Zhao W, et al. Research progress of Dengue virus genome. Progr Microbiol Immunol. 2007;35:80-3.

25. Yao ZH, Dong GM, Yu YX, et al. Sequence analysis of whole gene of strain L99 for preparation of inactivated EHF vaccine. Chin J Biologicals. 2001;14(2):72-4.

26. Sun Y, Liang M, Qu J, et al. Early diagnosis of novel SFTS bunyavirus infection by quantitative real-time RT-PCR assay. J Clin Virol. 2012:53(1):48-53.

27. Sun J, Chai C, Lv H, et al. Epidemiological characteristics of severe fever with thrombocytopenia syndrome in Zhejiang Province, China. Int J Infect Dis. 2014:25:180-5

28. Cui N, Liu R, Lu QB, et al. Severe fever with thrombocytopenia syndrome bunyavirus-related human encephalitis. J Infect. 2015;70(1):52-9.

29. Zhang YZ, He YW, Dai YA, et al. Hemorrhagic fever caused by a novel Bunyavirus in China: pathogenesis and correlates of fatal outcome. Clin Infect Diseases. 2012:54(4):527-33.

30. Hayasaka D, Shimada S, Aoki K, et al. Epidemiological survey of severe fever with thrombocytopenia syndrome virus in ticks in Nagasaki, Japan. Trop Med Health. 2015;43(3):159-64.

31. (ChPC) CPC. Pharmacopoeia of People's Republic of China, vol. III. Beijing: MedSci Press; 2010.
32. Lam TT, Liu W, Bowden TA, et al. Evolutionary and molecular analysis of the emergent sever fever with thrombocytopenia syndrome virus. Epidemics. 2013;5(1):1-10.

33. Wang LN, Wu JM, Li JM, et al. Establishment of the first national standard for nucleic acid amplification technology assay for HCV RNA. Chin J Lab Med. 2006:29(4):354-7.

\section{Submit your next manuscript to BioMed Central and we will help you at every step:}

- We accept pre-submission inquiries

- Our selector tool helps you to find the most relevant journal

- We provide round the clock customer support

- Convenient online submission

- Thorough peer review

- Inclusion in PubMed and all major indexing services

- Maximum visibility for your research

Submit your manuscript at www.biomedcentral.com/submit

) Biomed Central 